\title{
Penerapan Customer Relationship Management (CRM) Berbasis Website Terhadap Penilaian Pelanggan
}

\author{
Era Era Hia ${ }^{1}$, Muhammad Khaidir Fahram ${ }^{2}$, Siti Nurhasanah ${ }^{3}$ \\ ${ }^{1,3}$ Program Studi Sistem Informasi Universitas Raharja, \\ ${ }^{2}$ Program Studi Teknik Informatika STTIKOM Insan Unggul Cilegon \\ E-mail: ${ }^{1}$ eraerahia@ raharja.info, ${ }^{2}{ }^{2}$ khaidir@fahram.com, ${ }^{3}$ sitinur.hasanah@ raharja.info
}

\begin{abstract}
Abstrak
CRM adalah strategi pemasaran untuk menciptakan dan memelihara suatu hubungan yang baik terhadap pelanggan serta mengurangi pindahnya atau perginya pelanggan ke pesaing lain. Sistem CRM pada PT. Wingoh Albinda masih menggunakan semi komputerisasi yaitu Microsoft excel dalam mengelola datanya, sehingga menimbulkan beberapa masalah dalam hal pelayanan yang telambat, respon terhadap pelanggan tidak maksimal. Penelitian ini menyajikan analisis pengembangan CRM berbasis web pada sistem informasi pemasaran pada PT. Wingoh Albinda. Hasilnya adalah sistem CRM berbasis web yang dapat mengelola data pelanggan, promosi produk, data penjualan produk dan pengelolaan layanan pelanggan yang digunakan untuk menyimpan pertanyaan, keluhan dan penilaian pelanggan untuk menciptakan hubungan baik dengan pelanggan. Sistem ini diharapkan dapat menjaga hubungan baik terhadap pelanggan.
\end{abstract}

Kata Kunci : Customer Relationship Management (CRM), Penilaian, Pelanggan, Web

\begin{abstract}
CRM is a marketing strategy to create and maintain a good relationship with customers and reduce customer turnover or departure to other competitors. CRM system at PT. Wingoh Albinda still uses semi-computerization, namely Microsoft excel in managing its data, causing several problems in terms of late service, the response to customers is not optimal. This study presents an analysis of web-based CRM development on a marketing information system at PT. Wingoh Albinda. The result is a web-based CRM system that can manage customer data, product promotions, product sales data and customer service management which is used to store customer inquiries, complaints and ratings to create good relationships with customers. This system is expected to maintain good relations with customers
\end{abstract}

Keywords: Customer Relationship Management (CRM), Assessment, Customers, Web

\section{PENDAHULUAN}

Persaingan bisnis yang ketat saat ini menuntut perusahaan untuk fokus pada kebutuhan yang diinginkan oleh konsumen. Perusahaan mulai mengubah pola pikir dan orientasi keuntungan terhadap faktor-faktor potensial lainnya seperti minat pelanggan dan tingkat kepuasan pelanggan menjadi faktor utama yang harus diperhatikan oleh perusahaan. dengan kebutuhan dan keinginan mereka. Terlihat bahwa perusahaan tidak lagi hanya memikirkan keuntungan semata tetapi mulai memperhatikan sektor potensial lainnya yang dapat mempertahankan atau meningkatkan pendapatan sehingga kepentingan pelanggan menjadi perhatian utama perusahaan. Kondisi persaingan bisnis yang terjadi saat ini membuat perusahaan harus mengetahui target pasar yang dibidik dan tingkat kualitas produk atau jasanya. Selain itu, faktor penting yang harus diperhatikan oleh perusahaan dalam menghadapi 
persaingan bisnis adalah tingkat nilai yang dapat diberikan kepada pelanggan dan cara memperlakukan pelanggan dari hari ke hari. Beberapa penelitian menunjukkan bahwa mempertahankan pelanggan yang sudah ada lebih menguntungkan daripada menarik pelanggan baru.

Dengan munculnya teknologi digital seperti internet, konsumen yang semakin terinformasi saat ini mengharapkan perusahaan untuk melakukan lebih dari sekadar menghubungkan mereka, lebih dari memuaskan mereka, dan bahkan lebih dari sekadar menyenangkan mereka. Saat ini banyak perusahaan yang menggunakan berbagai cara dalam upaya meningkatkan Customer Relationship Management (CRM) secara luas dapat didefinisikan sebagai upaya yang dilakukan untuk menciptakan, mengembangkan, dan memelihara hubungan yang sehat dan langgeng dengan pelanggan menggunakan teknologi. (Ansari, 2020) Secara umum dapat dikatakan bahwa tujuan dari setiap strategi Customer Relationship Management (CRM) adalah untuk mengembangkan hubungan yang menguntungkan dengan pelanggan. sasaran utama dari customer relationship management adalah untuk meningkatkan pertumbuhan jangka panjang dan profitabilitas perusahaan melalui pengertian yang lebih baik terhadap kebiasaan (behavior) pelanggan. (Sa'adah \& Susi, 2021)

Beberapa penelitian terkait dengan hal ini dinataranya : Penelitian yang dilakukan oleh (Supriatna \& Heru, 2019) dengan judul Penerapan Customer Relationship Management (CRM) Sebagai Upaya Meningkatkan Kepuasan Dan Loyalitas Pelanggan Pada Gelora Mukti Sport Berbasis Web. Hasil yang diperoleh dari Sistem Customer Relationship Management (CRM) dengan metode Waterfall untuk mempermudah pengelolaan produk dan data pelanggan di Gelora Mukti Sport telah berhasil dibangun untuk membantu toko Gelora Mukti Sport dalam menjual produk sesuai dengan kebutuhannya. Implementasi fungsional dari diskon, dompet, voucher, poin dan saran telah berhasil dibangun seperti yang diharapkan; Penelitian yang dilakukan oleh (Sabatini, 2018) dengan judul Penerapan Customer Relationship Management (CRM) Berbasis Website Di CV Riz Plakat Jaya Di Surabaya. Hasil yang diperoleh dari penelitian ini menggambarkan bentuk Customer Relationship Management (CRM) dan penerapan Customer Relationship Management (CRM) yang selalu berjalan beriringan dalam setiap proses jual beli yang terjadi di Riz Plakat Jaya; Penelitian yang dilakukan oleh (Putra \& Evri, 2020) dengan judul Penerapan E-Customer Relationship Pada PT. Kimia Farma Berbasis Web. Alasan penelitian mengenai CRM karena melalui penggunaan E-CRM, perusahaan bisa mendapatkan keuntungan untuk penjualan, pemasaran, layanan dan aktivitas perusahaan lainnya. E-CRM juga dapat memudahkan pelanggan untuk mendapatkan informasi yang mereka butuhkan dari perusahaan. Hal ini merupakan sarana untuk menjaga hubungan perusahaan dengan pelanggan dalam rangka mewujudkan loyalitas pelanggan, dengan merancang sistem baru, maka pelanggan dan perusahaan akan dapat bekerja sama dengan baik dalam transaksi pemasaran; Penelitian yang dilakukan oleh (Amatullah et all., 2018) dengan judul Penerapan Strategi Customer Relationship Management (CRM) Pada Sistem Informasi Pelayanan Pelanggan Studi Kasus : Rumah Kreatif Ogan Ilir Indralaya. Tujuan penerapan strategi Customer Relationship Management (CRM) yang dibuat adalah untuk mempertahankan pelanggan yang sudah ada dengan meningkatkan kepuasan pelanggan terhadap layanan. Tingkat kepuasan pelanggan akan diketahui dari kuesioner yang hasilnya akan digunakan untuk menghitung metode Servqual (Service Quality). Dengan diterapkannya strategi Customer Relationship Management pada sistem informasi layanan pelanggan diharapkan penyajian informasi dan layanan dapat lebih cepat dan mudah; Penelitian yang dilakukan oleh (Zakaria \& Marlia, 2019) dengan judul Perancangan Sistem Informasi Customer Relationship Management (CRM) untuk Meningkatkan Loyalitas dan Pelayanan Customers Berbasis Web dengan Model Waterfall. Berdasarkan hasil implementasi dan pengujian sistem dapat disimpulkan bahwa penerapan sistem pengolahan data telah terintegrasi satu sama lain sehingga dapat meningkatkan kualitas pelayanan kepada pelanggan, dalam implementasi sistem pengaduan pelanggan telah sangat membantu perusahaan dalam mengetahui keluhan berupa kritik dan saran untuk meningkatkan pelayanan kepada pelanggan. 


\section{METODE PENELITIAN}

\subsection{Jenis Penelitian}

Metode yang digunakan dalam penelitian ini menggunakan pendekatan kualitatif, yaitu melakukan penelitian secara langsung, intensif, rinci dan mendalam terhadap suatu organisasi, lembaga atau fenomena tertentu serta dengan mengamati objek (kegiatan atau peristiwa). Penelitian kualitatif adalah pengumpulan data pada suatu latar alamiah dengan maksud menafsirkan fenomena yang terjadi dimana penelitian adalah sebagai instrumen kunci, pengambilan sampel sumber data dilakukan secara purposive dan snowbaal, teknik pengumppulan dengan trianggulasi (gabungan), analisis data bersifat induktif/kualitatif, dan hasil penelitian kualitatif lebih menekankan makna dari pada generalisasi. (Anggito \& Setiawan, 2018) Penelitian ini juga bersifat deskriptif, yaitu mendeskripsikan dan menyajikan fakta secara sistematis tentang keadaan objek yang sebenarnya. dalam menggunakan jenis penelitian deskriptifn masalah yang dirumuskan harus layak untuk diangkat, mengandung nilai ilmiah, dan tidak bersifat terlalu luas, tujuannya pun tidak boleh terlalu luas dan menggunakan data yang bersifat fakta dan bukan opini. (Ramdhan, 2021)

\subsection{Teknik Pengumpulan Data}

Metode pengumpulan data adalah bagaimana memperoleh data dalam melakukan kegiatan penelitian. Beberapa metode tersebut antara lain wawancara, observasi, studi dokumentasi.

a. Wawancara

Dalam penelitian ini, peneliti melakukan wawancara dengan orang-orang yang terlibat langsung dalam penanganan Customer Relationship Management (CRM). Selain itu, wawancara dalam penelitian ini dilakukan dengan dua cara, (1) wawancara tidak terencana yaitu peneliti melakukan wawancara informal dan spontan dengan subjek penelitian, (2) terencana, yaitu peneliti melakukan wawancara dengan subjek penelitian sesuai dengan pertanyaan yang telah disiapkan oleh penelitian.

b. Observasi

Observasi adalah suatu metode pengamatan data melalui mengamati perilaku dalam situasi tertentu dan kemudian mencatat peristiwa yang diamati secara sistematis dan menafsirkan peristiwa yang diamati, sehingga hasil pengamatan tersebut dapat dijadikan sebagai sumber data yang akurat dan terpercaya yang dapat digunakan untuk menjawab permasalahan.

c. Studi Pustaka

Studi Pustaka adalah segala upaya yang dilakukan peneliti untuk mengumpulkan informasi yang relevan dengan topik atau masalah yang akan atau sedang dipelajari. Informasi ini dapat diperoleh dari buku-buku ilmiah, laporan penelitian, artikel ilmiah, tesis dan disertasi, peraturan, anggaran dasar, buku tahunan, ensiklopedia dan sumber tertulis dan elektronik lainnya.

\section{HASIL DAN PEMBAHASAN}

\section{Use Case Diagram Customer Relationship Management (CRM)}




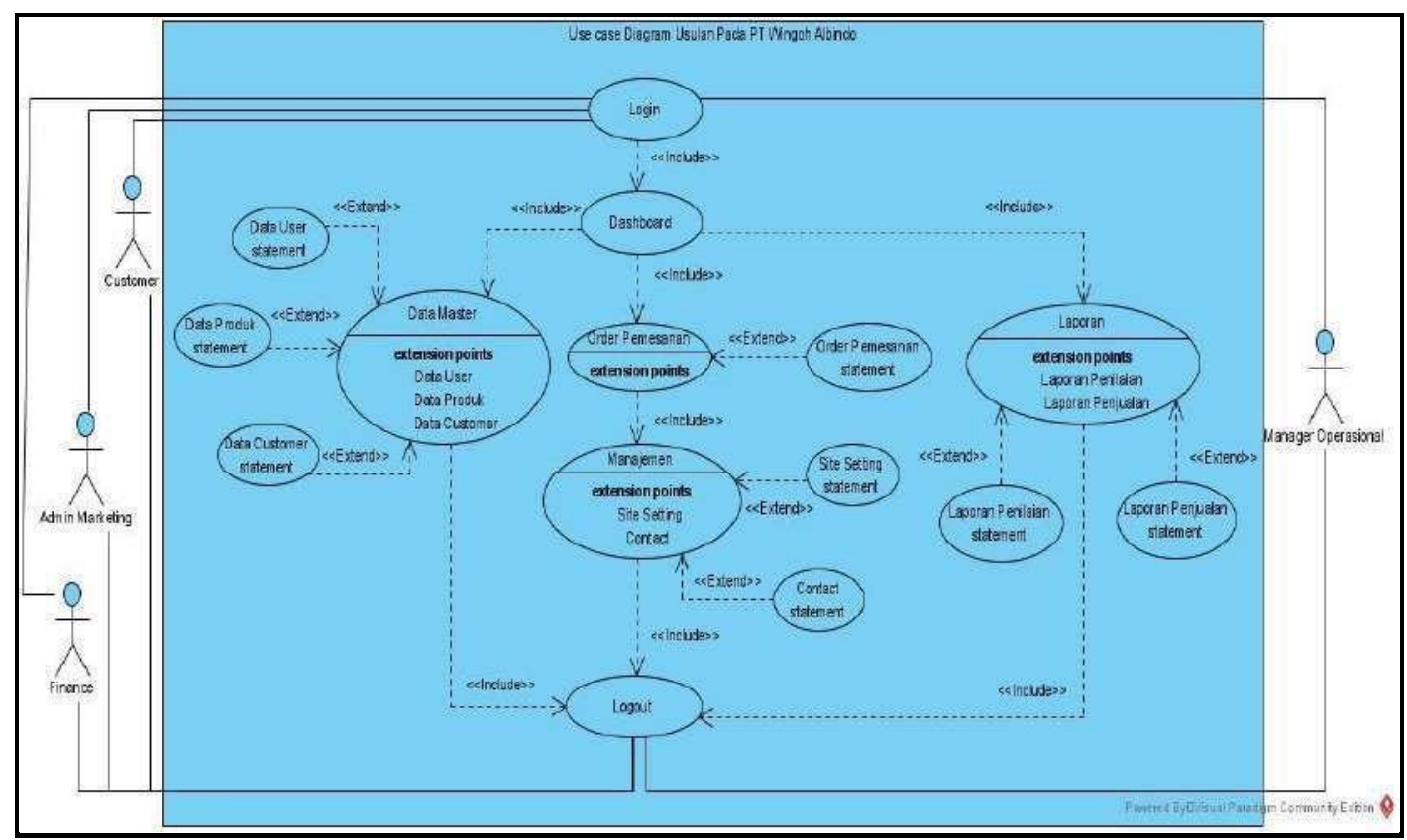

Gambar 1 usecase diagram CRM

Use case diatas menggambarkan CRM pada penilaian pelanggan (customer) yang terdiri dari 4 aktor yang dapat mengakses sistem yaitu pelanggan (customer), admin marketing, staff finance, dan manager operasional., dalam sistem terdapat beberapa menu yang dapat diakses oleh setiap pengguna sehingga tercipta lah laporan mengenai CRM terhadap penilaian customer (pelanggan)

2. Menu Pemesanan

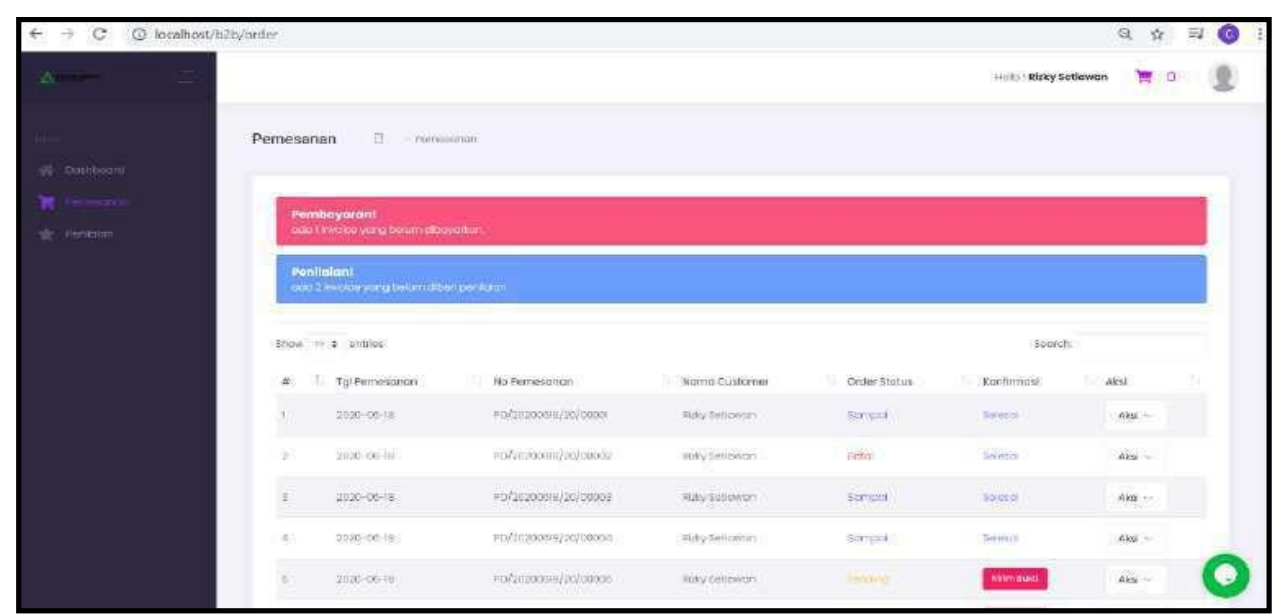

Gambar 2. Menu Pemesanan

Menampilkan status pemesanan (orderan), apakah customer sudah menerima atau belum produk yang telah dikirim.

3. Penilaian Customer 


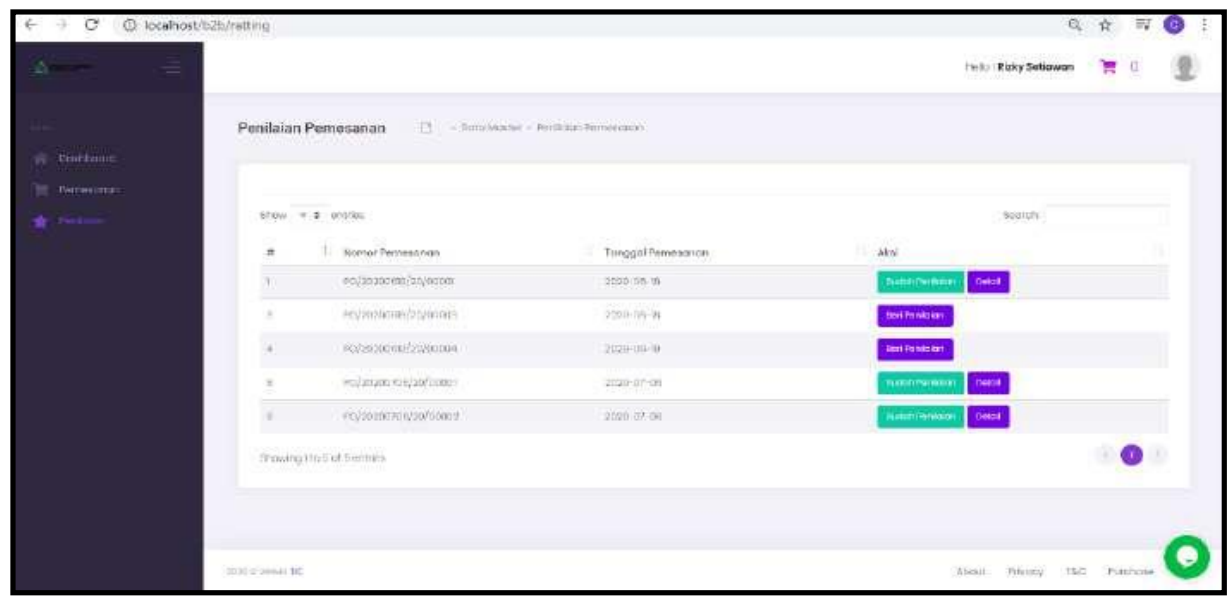

Gambar 3. Penilaian Customer (Pelanggan)

Menampilkan penilaian dari seluruh customer (pelanggan) atas pemesanan dan penerimaan barang

4. Menu Laporan Penilaian

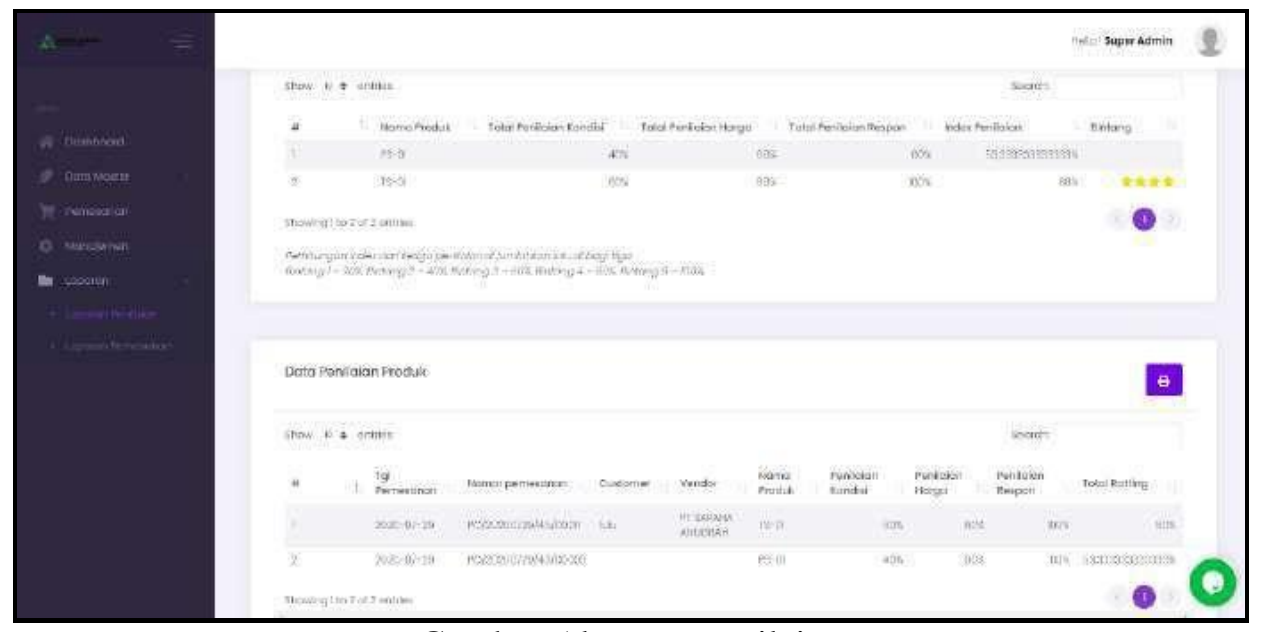

Gambar 5 laporan penilaian

Menampilkan laporan penilaian customer (pelanggan) untuk mengetahui penilaian yang telah diberikan oleh customer (pelanggan)

5. Tampilan Menu Laporan Penjualan 


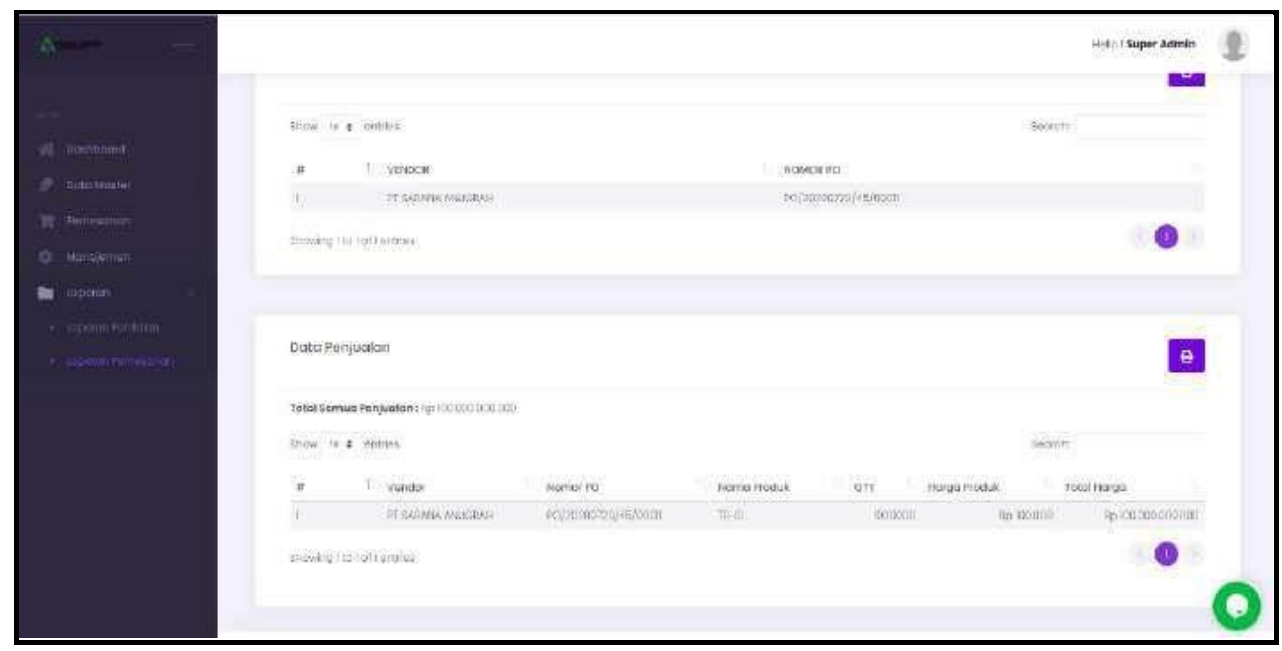

Gambar 6 laporan penjualan

Menampilkan laporan penjualan produk untuk mengetahui setiap penjualan

\section{KESIMPULAN} bahwa:

Berdasarkan hasil implementasi dan pengujian sistem CRM, maka dapat disimpulkan

1. Penerapan sistem pengolahan data telah terintegrasi satu sama lain sehingga dapat meningkatkan kualitas pelayanan kepada pelanggan

2. Penerapan sistem pengaduan pelanggan sangat membantu perusahaan dalam mengetahui keluhan berupa kritik dan saran untuk meningkatkan pelayanan kepada pelanggan

\section{SARAN}

Untuk dapat memperbaiki dan menyempurnakan sistem aplikasi yang peneliti rancang yaitu: diharapkan sistem ini dapat dikembangkan menjadi aplikasi mobile

\section{DAFTAR PUSTAKA}

[1] Ansari, H. (2020). Customer Relationship Management. (n.p.): Independently Published.

[2] Anggito, A., \& Setiawan, J. (2018). Metodologi penelitian kualitatif. CV Jejak (Jejak Publisher)

[3] Ramchan, M. 2021. Metode Penelitian. surabaya : Cipta media Nusantara (CMN)

[4] Supriatna, A., \& Heru, B. 2019. Penerapan Customer Relationship Management (CRM) Sebagai Upaya Meningkatkan Kepuasan Dan Loyalitas Pelanggan Pada Gelora Mukti Sport Berbasis Web. JURNAL NUANSA INFORMATIKA, 13(2), 11-18

[5] Sabatini, RR. 2018. "Penerapan Customer Relationship Management (CRM) Berbasis Website Di CV Riz Plakat Jaya Di Surabaya”. Fakultas Dakwah Dan Komunikasi. Komunikasi. Universitas Islam Negeri Sunan Ampel Surabaya 
[6] Putra, BB., \& Evri, E. 2020. Penerapan E-Customer Relationship Pada PT. Kimia Farma Berbasis Web. InfoSys Journal, 5(1), 56-36

[7] Sa'adah, L., \& Susi, I. 2021. Penerapana Customer Relationship Management Pada CV. Zam - Zam. Jombang : LPPM Universitas KH. A. Wahab Hasbullah

[8] Amatullah, S., Syafitri, H., Delima, R., \& Ibrahim, A. (2018). Penerapan Strategi Customer Relationship Management (CRM) Pada Sistem Informasi Pelayanan Pelanggan Studi Kasus : Rumah Kreatif Ogan Ilir Indralaya. Jurnal Teknologi Informasi Dan Ilmu Komputer, 5(2), 225-230

[9] Zakaria, H., \& Marlia, A. E. (2019). Perancangan Sistem Informasi Customer Relationship Management (CRM) untuk Meningkatkan Loyalitas dan Pelayanan Customers Berbasis Web dengan Model Waterfall. Jurnal Teknologi Sistem Informasi dan Aplikasi, 2(2), 66-72. 